\title{
Corynebacterium pseudotuberculosis mastitis in Egyptian dairy goats
}

\author{
A. M. Nabih' ${ }^{1}$, Hany A. Hussein ${ }^{2,3}$, Safaa A. El-Wakeel ${ }^{1}$, Khaled A. Abd El-Razik² and A. M. Gomaa ${ }^{1}$
}

1. Department of Mastitis and Neonatal Diseases, Animal Reproduction Research Institute, Agriculture Research Center, Giza, Egypt; 2. Department of Animal Reproduction and AI, Veterinary Research Division, National Research Centre, Dokki, Giza, Egypt; 3. Guangdong Haid Institute of Animal Husbandry and Veterinary (GHIAHV), Guangzhou, Guangdong, China. Corresponding author: Hany A. Hussein, e-mail: hnyhussein2@yahoo.com

Co-authors: AMN: ashraf_nabih27@yahoo.com, SAE: safaaalwakeel@yahoo.com, KAA: khaled707@hotmail.com, AMG: alaagomaa20@yahoo.com

Received: 24-07-2018, Accepted: 01-10-2018, Published online: 13-11-2018

doi: 10.14202/vetworld.2018.1574-1580 How to cite this article: Nabih AM, Hussein HA, El-Wakeel SA, Abd El-Razik KA, Gomaa AM (2018) Corynebacterium pseudotuberculosis mastitis in Egyptian dairy goats, Veterinary World, 11(11): 1574-1580.

\begin{abstract}
Background and Aim: Mastitis is an important threat facing goat milk industry and is the most common cause of culling. Efficient control of mastitis, based on efficient diagnosis of diseased animals, would improve milk production and reproductive efficiency. In subclinical mastitis (SCM), infected goats demonstrate neither udder symptoms nor abnormal milk. Corynebacterium pseudotuberculosis is an infectious causative agent of mastitis, mostly results as an extension of infection from the supramammary lymph node, and causes financial losses in the goat industry. This study aimed to estimate the prevalence of SCM with emphasis on C. pseudotuberculosis mastitis in Egyptian dairy goats in the selected farms.
\end{abstract}

Materials and Methods: A total of 336 half milk samples were collected from 177 dairy goats of various crossbreeds, in mid-to-late lactation period, after clinical examination. All samples were examined bacteriologically, while somatic cell count (SCC) was determined only in 180 half milk samples of the clinically healthy milk samples. The isolated and identified $C$. pseudotuberculosis was examined for evidence of virulence genes (Phospholipase D [pld] and $\beta$-subunit of RNA polymerase $[r p o B]$ ) by polymerase chain reaction (PCR).

Results: The prevalence of clinical mastitis was $30.5 \%$, while $69.5 \%$ of animals were apparently healthy and secreted milk was normal. Of those 180 clinically healthy half milk samples, 96 milk samples (53.33\%) showed SCM as detected by SCC (SCC $\geq 1,000,000$ cells $/ \mathrm{ml})$. Coagulase-negative staphylococci were the most prevalent bacteria $(41.96 \%)$, then Staphylococcus aureus (37.5\%) and C. pseudotuberculosis (7.14\%). Molecular diagnosis of virulence genes revealed evidence of pld gene in 16 isolates (66.66\%), and rpoB gene in 6 samples $(25 \%)$ of the 24 bacteriologically isolated C. pseudotuberculosis. Here, we describe, for the $1^{\text {st }}$ time, isolation and identification of C. pseudotuberculosis from milk of does suffering from SCM in Egypt.

Conclusion: C. pseudotuberculosis must be considered for routine bacteriological examination of milk from dairy goats, particularly herds with a history of caseous lymphadenitis. Pld gene-based PCR is more reliable than $r p o B$ gene-based ones for the diagnosis of C. pseudotuberculosis.

Keywords: bacteriological investigation, caprine, Corynebacterium pseudotuberculosis, mastitis, phospholipase D, $\beta$-subunit of RNA polymerase.

\section{Introduction}

The past two decades have seen intensification in dairy goat production with a significant increase in the number of goats worldwide $[1,2]$, as nutritional qualities of goat milk are to great extent similar to human milk, and less allergenic for human than bovine milk [3].

Mastitis is the most serious disease in dairy goats due to financial losses attributed to its negative impact on milk quantity and components $[4,5]$ and is the main cause of culling for sanitary reasons [6]. Besides, milk fom mastitic udder has public health hazard [7].

Copyright: Nabih, et al. Open Access. This article is distributed under the terms of the Creative Commons Attribution 4.0 International License (http://creativecommons.org/licenses/by/4.0/), which permits unrestricted use, distribution, and reproduction in any medium, provided you give appropriate credit to the original author(s) and the source, provide a link to the Creative Commons license, and indicate if changes were made. The Creative Commons Public Domain Dedication waiver (http://creativecommons.org/ publicdomain/zero/1.0/) applies to the data made available in this article, unless otherwise stated.
In dairy goats, the incidence of clinical mastitis may not exceed 5\%, while subclinical mastitis (SCM) is common and about 6 times more than clinical affections [8] and associated with production loss, decreased milk quality, increased replacement cost, and considerable treatment expenses $[9,10]$.

In dairy goats, the problem of SCM is exacerbated as infected goats demonstrate neither udder symptoms nor abnormal milk; hence, the identification of disease is delayed [11]. Thus, SCM must be considered as a serious economic disease [12]. In goats, SCM is mainly caused by Staphylococcus aureus, coagulase-negative staphylococci (CNS), Streptococci agalactiae, Streptococci Group C, and Mycoplasma spp. [13].

Corynebacterium pseudotuberculosis is one of the infectious causative agents of mastitis, occasionally encountered in goat and sheep. C. pseudotuberculosis mastitis is likely to be an extension of infection from the adjacent lymph node [14]. C. pseudotuberculosis 
mastitis was reported in cattle $[15,16]$. C. pseudotuberculosis is the causative agent of caseous lymphadenitis (CLA) [17], characterized by abscess formation in several organs in small ruminants [18]. CLA is a worldwide distributed disease [19], which causes significant financial losses in goat and sheep industry due to decreased milk production, wasting, low reproductive rates, and condemnation of carcasses due to internal abscesses [20,21]. Although rare, C. pseudotuberculosis has a public health hazard. It causes lymphadenitis in human and acquired through close contact with diseased animals $[22,23]$.

Phospholipase D $(P l d)$ is the most important virulence factor in C. pseudotuberculosis [24]. Pld is an exotoxin, induces increased vascular permeability through catalyzing sphingomyelin dissociation, resulting in spread and survival of $C$. pseudotuberculosis in cells, and, consequently, the invasion of the body and transport by phagocytes to regional lymph nodes $[25,26]$.

Pld gene detection is used as a diagnostic tool for C. pseudotuberculosis. More recently, analysis of partial gene sequences from the $\beta$-subunit of RNA polymerase $(r p o B)$ has been used for the identification of Corynebacterium species than analyses based on $16 \mathrm{~S}$ rDNA. This method has also been successfully used as a powerful identification tool for mycobacterial species [27]. As well as, many authors propose that it may be used to complement the 16S rRNA gene analysis in the phylogenetic studies of Corynebacterium and Mycobacterium species [21,28].

There are several methods for diagnosis of intra-mammary infection (IMI), of those methods is bacteriological examination of milk [29]. However, bacteriological examination is mostly expensive, time-consuming, and milk culture may yield no bacteria from truly infected glands with very low numbers of pathogens or due to inhibitory effect of residual antimicrobials [30]. Consequently, other diagnostic methods such as indirect measurements of somatic cell count (SCC) with the California mastitis test were developed $[13,31]$. SCC is commonly used worldwide as an indicator for SCM and to evaluate the efficiency of control programs of mastitis in dairy cattle and buffalo [32]. Unfortunately, interpretation of SCC is difficult in goats, because the relationship of bacterial infections and SCC values is not as simple as in cattle since SCC is significantly affected by several non-infectious factors. Other intrinsic factors such as time and number of lactation, milking time, milking routine, seasonality, and food affect SCC [33,34]. In addition, the apocrine nature of milk secretion in goat results in the presence of cytoplasmic particles or epithelial debris hinders the use of DNA-specific counters mandatory [5].

Recently, molecular diagnosis of pathogens has been introduced. Polymerase chain reaction (PCR) and multiplex PCR have been explored as rapid, sensitive, and reliable approaches for the diagnosis of mastitis-causing pathogens [35-37].
Therefore, the aim of this study was to estimate the SCM prevalence of with emphasis on C. pseudotuberculosis mastitis in Egyptian dairy goats in the selected farms.

\section{Materials and Methods \\ Ethical approval}

All samples were collected as per standard sample collection procedure without giving any stress or harm to the animals. The present work was approved by the Ethical Committee for Medical Research at the National Research Centre and Animal Care Guidelines of the General Organization for Veterinary Services, Egypt.

\section{Animals}

A total of 177 dairy goats of various crossbreeds located in El Fayoum Governorate, Egypt, were employed in this study. All goats were in mid-to-late lactation at sampling, and some of these animals suffered from CLA with a history of chronicity of infection in these farms (Figure-1). Animals were subjected to clinical examination for the detection of any clinical abnormalities with special attention to the udder by visual inspection and palpation for the detection of clinical mastitis according to Kelly [38].

\section{Samples}

A total of 336 milk samples collected from 177 dairy goats (mastectomy was recorded in six halves, and complete atrophy in one half was recorded in 12 animals) were employed in this study. $15 \mathrm{ml}$ of milk was collected in a sterile tube under strict hygienic measures from each half after disinfection of the teat with $70 \%$ alcohol. The first three squirts from each half were discarded. Milk samples were kept on ice and transferred immediately to the laboratory for the assessment of SCC and bacteriological examination within $24 \mathrm{~h}$.

\section{SCC}

Milk SCC was assessed in 180 apparently normal half milk samples by The NucleoCounter ${ }^{\circledR}$ SCC instrument that is based on ChemoMetec's proven technology of Fluorescence image cytometry. This method uses the single-use SCC-Cassette ${ }^{\mathrm{TM}}$ sampling and measuring device, the NucleoCounter ${ }^{\circledR}$ SCC- $100^{\mathrm{TM}}$ system. The measurement range of the NucleoCounter ${ }^{\mathbb{B}}$ SCC$100^{\mathrm{TM}}$ is between $1 \times 10^{4}$ cells $/ \mathrm{ml}$ and $2 \times 10^{6}$ cells $/ \mathrm{ml}$.

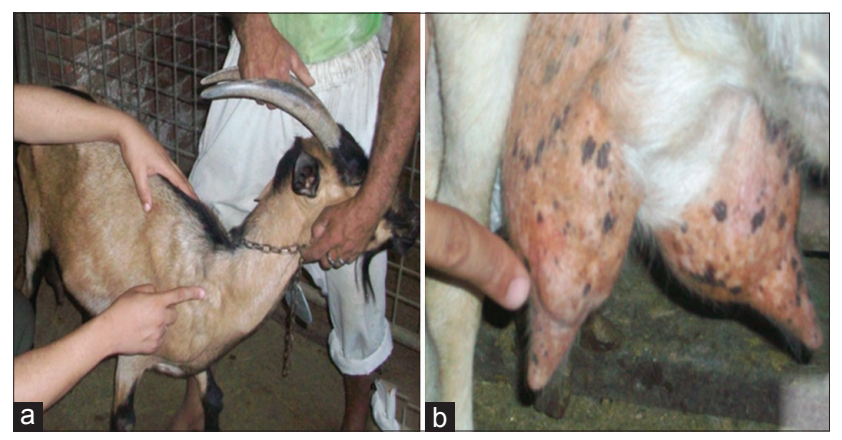

Figure-1: Clinical examination of goats. (a) Case of caseous lymphadenitis infection in prescapular lymph node. (b) Case of abscess in mammary gland with internal palpable abscess. 


\section{Bacteriological examination}

Bacteriological examination of milk samples was performed according to Sztachańska et al. [39]. Briefly, $10 \mu \mathrm{l}$ of milk were cultivated on Blood Agar Base (BioMérieux Poland), MacConkey Agar (BTL, Poland), Mannitol salt agar (Oxoid Ltd., England), and Edwards Medium (Oxoid Ltd., England). Plates were incubated at $37^{\circ} \mathrm{C}$ and read at 24 and $48 \mathrm{~h}$ later. Colonies were identified by their colony morphology and Gram staining. Detailed identification of isolated bacteria was performed using standard biochemical tests and API-Coryne system (bioMérieux Poland).

For C. pseudotuberculosis diagnosis, milk samples were inoculated onto brain heart infusion (BHI) agar supplemented with 5\% defibrinated sheep blood and chocolate agar. The plates were incubated aerobically for approximately $48 \mathrm{~h}$ at $37^{\circ} \mathrm{C}$. Colonies that morphologically resembled $C$. pseudotuberculosis were Gram stained. Gram-positive colonies were further tested for urease activity, synergistic hemolytic activity with Christie, Atkins, and Munch-Peterson factor from Rhodococcus equi and carbohydrate fermentation (glucose, lactose, and sucrose). Strains that were positive for urease and glucose fermentation and negative for lactose and sucrose fermentation were identified as C. pseudotuberculosis [40].

\section{Molecular diagnosis of $\boldsymbol{C}$. pseudotuberculosis [28] Extraction of DNA}

According to the above-mentioned bacteriological isolation and identification, C. pseudotuberculosis colonies were grown in BHI broth (BHI; Oxoid) at $37^{\circ} \mathrm{C}$ for $48-72 \mathrm{~h}$ before DNA extraction. Bacterial DNA was extracted using QIAamp DNA Mini Kit (Catalogue no. 51304) according to the prescribed instructions.

\section{Primers, amplification conditions, and agarose gel electrophoresis}

The oligonucleotide primers used in this study are listed in Table-1. Primers targeting the Pld and rpoB genes of $C$. pseudotuberculosis were obtained from previously published work $[41,42]$.

Amplification reaction mixtures were prepared in volumes of $50 \mu \mathrm{L}$ containing $5 \mu \mathrm{L}$ of $10 \times$ PCR master mix (Fermentas, Vilnius, Lithuania), $5 \mu \mathrm{l}$ of $25 \mathrm{mM}$ $\mathrm{MgCl} 2,0.2 \mu \mathrm{L}$ of $10 \mathrm{mM}$ dNTP mixture (Fermentas), $2 \mathrm{U}$ of Taq DNA polymerase (Fermentas), 1 mol of $25 \mathrm{mM}$ each primer, and $5 \mu \mathrm{L}$ of template. PCR was performed in a DNA thermocycler (Thermo Electron Corp., Waltham, MA, USA) and amplifications were performed using protocols listed in Table-2. The negative control contained sterile, DNase/RNase free, and DEPC (diethylpyrocarbonate)-treated water (Applichem) instead of DNA template. As a positive control, DNA isolated from C. pseudotuberculosis $\mathrm{Pl}$ 18 strain (isolated strain from a sheep with CLA). The amplified products were analyzed by electrophoresis on a $2 \%(\mathrm{w} / \mathrm{v})$ agarose gel against gel pilot $100 \mathrm{bp}$ ladder (Qiagen, USA, Cat. No. 239035). Amplified products were visualized using a gel documentation system, and the data were analyzed through computer software. PCR products with a molecular size of $203 \mathrm{bp}(\mathrm{Pld})$ and $406 \mathrm{bp}(\mathrm{rpoB})$ were considered positive for $C$. pseudotuberculosis.

\section{Results}

Clinical examination of 177 dairy goats revealed that the presence of symptoms suggestive for clinical mastitis in 54 animals (30.5\%) and 123 animals $(69.5 \%)$ was apparently healthy with normal milk secretion (Table-3). Animals were diagnosed for clinical mastitis if suffer from pain on milking, swelling of udder, hardness, and necrosis in udder, decreased milk production, or changes in milk.

Bacteriological examination of 336 milk samples revealed that single infection in 147 milk samples $(43.75 \%)$, mixed infection in 84 milk samples (25\%), and 105 milk samples $(31.25 \%)$ did not show any microbial growth on the utilized media (Table-4). A total number of 315 bacterial isolates were recovered. The most predominant bacterial study was CNS (41.96\%) and S. aureus (37. 5\%). C. pseudotuberculosis was isolated and identified from 24 milk samples (7.14\%) (Table-5).

For SCC assessment, 96 milk samples (53.33\%) had $\mathrm{SC} \geq 1,000,000$ cells $/ \mathrm{ml}$ and represent SCM, and $84(46.67 \%)$ milk samples had $\mathrm{SCC} \leq 1,000,000$ cells $/ \mathrm{ml}$ (Table-6).

Table-1: List of oligonucleotide primers used in this study and their references.

\begin{tabular}{lllcc}
\hline Gene & Primers & Sequence $\left(\mathbf{5}^{{ }^{\prime} \rightarrow \mathbf{3}^{\prime} \mathbf{)}}\right.$ & PCR product & References \\
\hline PId & $P L D-F$ & ATAAGCGTAAGCAGGGAGCA & $203 \mathrm{bp}$ & {$[41]$} \\
& $P L D-R 2$ & ATCAGCGGTGATGTCTTCCAGG & & \\
$r p o B$ & C2700F & CGWATGAACATYGGBCAGGT & $406 \mathrm{bp}$ & {$[42]$} \\
& C3130R & TCCATYTCRCCRAARCGCTG & & \\
\hline
\end{tabular}

$P / d=$ Phospholipase $\mathrm{D}, \mathrm{PCR}=$ Polymerase chain reaction, $r p o B=\beta$-subunit of RNA polymerase

Table-2: Cycling conditions of the different primers during PCR.

\begin{tabular}{|c|c|c|c|c|c|c|}
\hline Gene & Primary denaturation & Secondary denaturation & Annealing & Extension & Number of cycles & Final extension \\
\hline $\begin{array}{l}P L D \\
\text { rpoB }\end{array}$ & $\begin{array}{l}94^{\circ} \mathrm{C} 5 \mathrm{~min} \\
94^{\circ} \mathrm{C} 5 \mathrm{~min}\end{array}$ & $\begin{array}{l}94^{\circ} \mathrm{C} 30_{s} \\
94^{\circ} \mathrm{C} 30^{\circ}\end{array}$ & $\begin{array}{l}56^{\circ} \mathrm{C} 30_{\mathrm{s}} \\
52^{\circ} \mathrm{C} 45^{2}\end{array}$ & $\begin{array}{l}72^{\circ} \mathrm{C} 30_{\mathrm{s}} \\
72^{\circ} \mathrm{C} 45^{2}\end{array}$ & $\begin{array}{l}35 \\
35\end{array}$ & $\begin{array}{l}72^{\circ} \mathrm{C} 10 \mathrm{~min} \\
72^{\circ} \mathrm{C} 10 \mathrm{~min}\end{array}$ \\
\hline
\end{tabular}

$P / d=$ Phospholipase $\mathrm{D}, \mathrm{PCR}=$ Polymerase chain reaction, $r p o B=\beta$-subunit of RNA polymerase 
Table-3: Results of clinical examination of 177 dairy goats.

\begin{tabular}{lc}
\hline Health status & Number of animals (\%) \\
\hline Clinical mastitis & $54(30.5)$ \\
Clinically healthy & $123(69.5)$ \\
Total & $177(100)$ \\
\hline
\end{tabular}

Table-4: Results of bacteriological examination of 336 quarter milk samples of 68 lactating cows.

\begin{tabular}{lc}
\hline Bacteriological status & Number of samples (\%) \\
\hline Negative samples & $105(31.25)$ \\
Single pathogen & $147(43.75)$ \\
Mixed infection & $84(25)$ \\
Total & $336(100)$ \\
\hline
\end{tabular}

Molecular detection of C. pseudotuberculosis virulence genes revealed that PCR-amplified DNA fragment of $203 \mathrm{bp}$ and specific for the Pld gene of C. pseudotuberculosis was evidenced in 16 samples of 24 bacteriologically diagnosed isolates as C. pseudotuberculosis (66.66\%) (Figure-2). While PCR amplified DNA fragment of $406 \mathrm{bp}$, and specific for the rpoB gene was evidenced in 6 samples of 24 bacteriologically diagnosed isolates as C. pseudotuberculosis (25\%) (Figure-3).

\section{Discussion}

Mastitis continues to be an important threat confronting the goat milk industry, particularly in developing countries where the goat milk production has an important socioeconomic role.

In this study, clinical examination of the udder of 177 dairy goats revealed that 54 animals (30.5\%) demonstrated clinical mastitis according to Blood and Radostits [43], and 123 animals (69.5\%) were clinically healthy and secreted milk was normal (Table-3).

Clinical mastitis is easy to be detected, while SCM is often difficult to recognize due to a lack of reliable diagnostic methods, particularly at the farm level. Herein, SCM was diagnosed by SCC estimation in milk secretion of 180 apparently healthy udder halves. Its incidence was $53.33 \%$.

The observed decreased milk yield during IMI was explained by Petersson-Wolfe et al. [44] that an influx of neutrophils will pass between milk-producing cells of mammary gland and into the alveolar lumen resulting in damage of milk-secreting cells.

The prevalence of SCM in dairy goats was estimated in previous studies to be $5-30 \%$ or even higher, with about 6 times the incidence of clinical affections [10]. Others reported that the proportion of SCM in udder halves was 35-70\% [45]. In Brazil, the prevalence of mastitis in dairy goats was about $75 \%$, and most of infections were subclinical [46].

In a recent study carried out in China, SCM was diagnosed in $45.82 \%$ of examined dairy goats [47], while it was $18 \%$ in Sweden [13] and $30.2 \%$ in India [48]. The authors attributed this high prevalence
Table-5: The identified pathogens with their prevalence rate in half milk samples.

\begin{tabular}{lc}
\hline Identified bacteria & Number of samples (\%) \\
\hline C. pseudotuberculosis & $24(7.14)$ \\
CNS & $141(41.96)$ \\
S. aureus & $126(37.5))$ \\
E. coli & $15(4.46)$ \\
Streptococci & $9(2.68)$ \\
Total & 315 \\
\hline
\end{tabular}

C. pseudotuberculosis= Corynebacterium

pseudotuberculosis, CNS=Coagulase-negative

staphylococci, S. aureus=Staphylococcus aureus,

E. coli=Escherichia coli

Table-6: Results of SCC estimation in 180 apparently healthy half milk samples.

\begin{tabular}{lc}
\hline SCC & $\mathbf{n}(\%)$ \\
\hline SCC $\geq 1,000,000$ & $96(51.67)$ \\
SCC $\leq 1,000,000$ & $84(46.67)$ \\
\hline SCC $=$ Somatic cell count
\end{tabular}

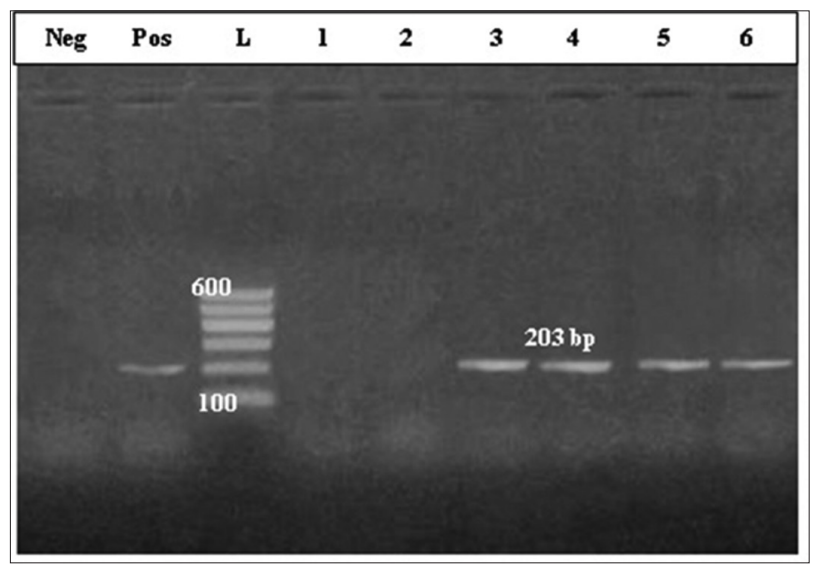

Figure-2: Polymerase chain reaction-amplified DNA fragment of $203 \mathrm{bp}$ and specific for the phospholipase D gene of Corynebacterium pseudotuberculosis. Lane 1: Control negative; Lane 2: Control positive; Lane 3: Molecular marker; Lanes 4-9 culture-positive samples.

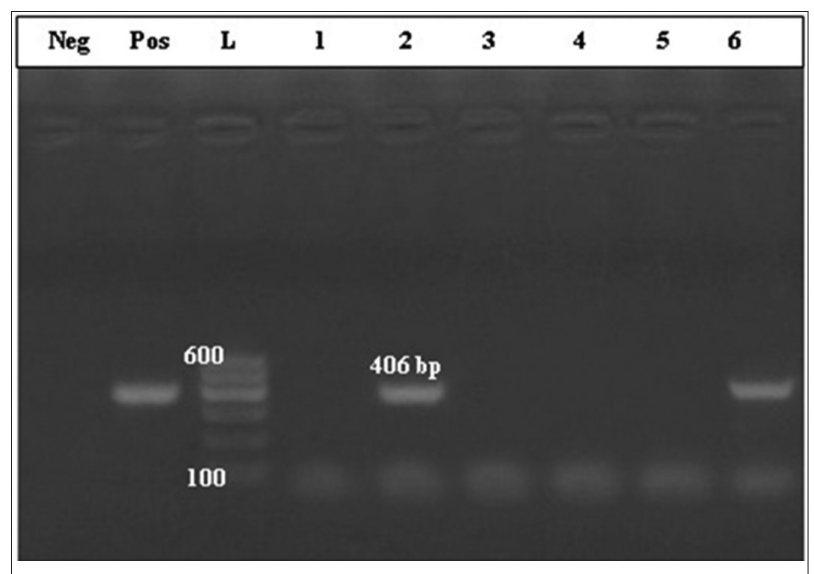

Figure-3: Polymerase chain reaction-amplified DNA fragment of $406 \mathrm{bp}$ and specific for the $\beta$-subunit of RNA polymerase gene of Corynebacterium pseudotuberculosis. Lane 1: Control negative; Lane 2: Control positive; Lane 3: Molecular marker; Lanes 4-9 culture-positive samples.

of SCM to be attributed to poor milking hygiene and the less awareness of SCM impact. Poor management 
represented by allowing infected animals to be in contact with healthy ones.

Our results concerning bacteriological findings proved single infection in 147 milk samples $(43.75 \%)$ and mixed infection in 84 milk samples (25\%); while $105(31.25 \%)$ milk samples were negative (Table-4), and the identified pathogens were CNS $(41.96 \%)$ and S. aureus (37.5\%). C. pseudotuberculosis was isolated and identified from 33 milk samples (7.14\%) (Table-5).

These results are too great extent in accord with previous studies, where staphylococci were recorded to be the most prevalent bacteria in cases of mastitis and account for $90 \%$ of isolated bacteria [10,49-51]. Furthermore, CNS recorded to have the capability of increasing SCC in goat milk and occur at over $50 \%$ in most studies of goat SCM [47]. About streptococci, it was reported to be the major pathogens for their severe inflammation, but they are less common in SCM in goats [47].

In 2015, a similar study carried on dairy goats and revealed that the incidence of IMI with CNS, $S$. aureus, Escherichia coli, and Streptococcus spp. was $59.52 \%, 15.24 \%, 11.43 \%$, and $10.95 \%$, respectively. The study concluded that CNS were the predominant pathogens [47]. Furthermore, Contreras et al. [52] recorded that CNS were the most predominant causative agent of mastitis in does. Another research group reported that CNS were the most predominant bacteria and encountered for $81.5 \%$ of milk samples from SCM infected does [53].

However, CNS are less pathogenic than $S$. aureus, it induces persistent SCM with markedly high SCC [52]. C. pseudotuberculosis was isolated and identified in 24 half milk samples (7.14\%), all of these samples had mixed infection mostly with CNS. Molecular diagnosis indicated that 16 isolates harbor gene sequence specific for Pld gene (Figure-2), while gene sequence specific for the $r p o B$ gene was diagnosed in six isolates only (Figure-3).

C. pseudotuberculosis infection results in acute suppurative mastitis or chronic encapsulated abscesses in the udder [54] causing economic losses due to decreased milk production, reproductive inefficiency, carcass condemnation, and rare cases of death [17]. C. pseudotuberculosis has been reported to have public health significance, causing lymphadenitis [55].

Once infection occurs in animal, the enlarged lymph nodes and abscesses can rupture and contaminate the milk, lambs, kids, other animals, and environment $[17,56]$. In the previous study, the prevalence of Corynebacterium sp. was $4.13 \%$ in dairy goats, mostly in association with E. coli [14]. This is in accordance with the results reported by McDougal et al. [57], who identify them as part of the microbial agents of mastitis in goats.

The identification of virulence factors involved in bacterial pathogenicity in mammary gland is essential for the development of effective control and prevention of SCM in goats and acts as ideal targets for accurate detection and identification.

To date, in C. pseudotuberculosis, the most important identified virulence determinant is Pld [58]. Pld increases vascular permeability in vivo. It has dermonecrotic properties and reduces the viability of neutrophils [59]. Studies with C. pseudotuberculosis strains with inactivated Pld demonstrated the necessity of Pld for CLA establishment [24,60]. Mutant strains were found to be unable to cause abscessation of the lymph nodes. Additional evidence for the importance of Pld in vivo comes from the observation that vaccination with formulations in which Pld is the major component protects against subsequent disease challenge [61].

\section{Conclusion}

C. pseudotuberculosis must be considered for routine bacteriological examination of milk from dairy goats, particularly herds with a history of CLA. $P l d$ gene-based PCR is more reliable than $r p o B$ genebased ones for the diagnosis of C. pseudotuberculosis.

\section{Authors' Contributions}

AMN, HAH, and AMG designed and planned for this study. HAH and KAA performed the fieldwork and collected the samples. AMN and SAE were responsible for bacteriological examination and SCC. HAH and AMG interpreted the results and reviewed the article. HAH drafted the manuscript. All authors read and approved the final manuscript.

\section{Acknowledgments}

The authors are thankful to Dr. Ahmed Erfaan, Animal Health Research Institute, Cairo, Egypt, for carrying out the molecular diagnosis of virulence genes in this study. The authors did not receive any specific fund for this study.

\section{Competing Interests}

The authors declare that they have no competing interests.

\section{References}

1. FAO. (2013), Food and Agriculture Organization of the United Nations statistical Databases. Available from: http:// www.faostat.fao.org. Retrieved on: 15-09-2018.

2. Skapetas, B. and Bampidis, V. (2016) Goat production in the world: Present situation and trends. Livest. Res. Rural Dev., 28(11). Available from: http://www.lrrd.org/lrrd28/11/ skap28200.html. Retrieved on: 15-09-2018.

3. Zenebe, T., Ahmed, N., Kabeta, T. and Kebede, G. (2014) Review on medicinal and nutritional values of goat milk. Acad. J. Nutr., 3(3): 30-39.

4. Barrón-Bravo, O.G., Gutiérrez-Chávez, A.J., ÁngelSahagún, C.A., Montaldo, H.H., Shepard, L. and ValenciaPosadas, M. (2013) Losses in milk yield, fat and protein contents according to different levels of somatic cell count in dairy goats. Small Rumin. Res., 113(2-3): 421-431.

5. Jimenez-Granado, R., Sanchez-Rodriguez, M., Arce, C. and Rodriguez-Estevez, V. (2014) Factors affecting somatic cell count in dairy goats: A review. Span. J. Agric. Res., 12(1): 133-150. 
6. Ceniti, C., Britti, D., Santoro, A.M.L., Musarella, R., Ciambrone, L., Casalinuovo, F. and Costanzo, N. (2017) Phenotypic antimicrobial resistance profile of isolates causing clinical mastitis in dairy animals. Ital. J. Food Saf., 6(2): 6612.

7. Gould, L.H., Mungai, E. and Behravesh, C.B. (2014) Outbreaks attributed to cheese: Differences between outbreaks caused by unpasteurized and pasteurized dairy products, United States, 1998-2011. Foodborne Pathog. Dis., 11(7): 545-551.

8. Contreras, A., Sierra, D., Sánchez, A., Corrales, J.C., Marco, J.C., Paape, M.J. and Gonzalo, C. (2007) Mastitis in small ruminants. Small Rumin. Res., 68(3): 145-153.

9. Koop, G., van Werven, T., Schuilling, H.J. and Nielen, M. (2010) The effect of subclinical mastitis on milk yield in dairy goats. J. Dairy Sci., 93(12): 5809-5817.

10. Gelasakis, A.I., Angelidis, A.S., Giannakou, R., Filioussis, G., Kalamaki, M.S. and Arsenos, G. (2016) Bacterial subclinical mastitis and its effect on milk yield in low-input dairy goat herds. J. Dairy Sci., 99(5): 1-11.

11. Haenlein, G.F.W. (2002) Relationship of somatic cell counts in goat milk to mastitis and productivity. Small Rumin. Res., 45(2): 163-178.

12. Silanikove, N., Merin, U., Shapiro, F. and Leitner, G. (2014) Subclinical mastitis in goats is associated with upregulation of nitric oxide-derived oxidative stress that causes reduction of milk antioxidative properties and impairment of its quality. J. Dairy Sci., 97(6): 3449-3455.

13. Persson, Y. and Olofsson, I. (2011) Direct and indirect measurement of somatic cell count as indicator of intramammary infection in dairy goats. Acta Vet. Scand., 53(1): 15.

14. Hristov, K., Popova, T., Pepovich, R. and Nikolov, B. (2016) Characterization of microbial causative agents of subclinical mastitis in goats in Bulgaria. Int. J. Curr. Microbiol. App. Sci., 5(8): 316-323.

15. Shpigel, N.Y., Elad, D., Yeruham, I., Winkler, M. and Saran, A. (1993) An outbreak of Corynebacterium pseudotuberculosis infection in an Israeli dairy herd. Vet. Rec., 133(4): 89-94.

16. Yeruham, I., Braverman, Y., Shpigel, N.Y., ChizovGinzburg, A., Saran, A. and Winkler, M. (1996) Mastitis in dairy cattle caused by Corynebacterium pseudotuberculosis and the feasibility of transmission by houseflies. Vet. $Q$., 18(3): 87-89.

17. Brown, C.C. and Olander, H.J. (1987) Caseous lymphadenitis of goats and sheep: A review. Vet. Bull., 57: 1-12.

18. Jung, B.Y., Lee, S.H., Kim, H.Y., Byun, J.W., Shin, D.H., Kim, D. and Kwak, D. (2015) Serology and clinical relevance of Corynebacterium pseudotuberculosis in native Korean goats (Capra hircus coreanae). Trop. Anim. Health Prod., 47(4): 657-661.

19. Guimarães, A.D.S., Borges, F., Pauletti, R.B., Seyffert, N., Ribeiro, D., Lage, A.P., Heinemann, M.B., Miyoshi, A., Maria, A., Gouveia, G., Federal, U., Gerais, D.M., Av, U., Carlos, A., Postal, C., Cep, U., Horizonte, B. and Gerais, M. (2011) Caseous lymphadenities: Epidimology, diagnosis and control. IIOAB J., 2(2): 33-43.

20. Arsenault, J., Girard, C., Dubreuil, P., Daignault, D., Galarneau, J.R., Boisclair, J., Simard, C. and Bélanger, D. (2003) Prevalence of and carcass condemnation from maedi-visna, paratuberculosis and caseous lymphadenitis in culled sheep from Quebec, Canada. Prev. Vet. Med., 59(1-2): 67-81.

21. Dorella, F.A., Pacheco, L.G.C., Oliveira, S.C., Miyoshi, A. and Azevedo, V. (2006) Corynebacterium pseudotuberculosis: Microbiology, biochemical properties pathogenesis and molecular studies of virulence. Vet. Res., 37(2): 201-218.

22. Hemond, V., Rosenstingl, S., Auriault, M.L., Galanti, M.J. and Gatfosse, M. (2009) Axillary lymphadenitis due to Corynebacterium pseudotuberculosis in a 63-year-old patient. Med. Mal. Infect., 39(2): 136-139.

23. Boschert, V., Berger, A., Konrad, R., Huber, I., Hörmansdorfer, S., Zöls, S., Eddicks, M., Ritzmann, M. and Sing, A. (2014) Corynebacterium species nasal carriage in pigs and their farmers in Bavaria, Germany: Implications for public health. Vet. Rec., 175(10): 248.

24. Hodgson, A.L.M., Carter, K., Tachedjian, M., Krywult, J., Corner, L.A., McColl, M. and Cameron, A. (1999) Efficacy of an ovine caseous lymphadenitis vaccine formulated using a genetically inactive form of the Corynebacterium pseudotuberculosis phospholipase D. Vaccine, 17(7-8): 802-808.

25. Baird, G.J. and Fontaine, M.C. (2007) Corynebacterium pseudotuberculosis and its role in ovine caseous lymphadenitis. J. Comp. Pathol., 137(4): 179-210.

26. Corrêa, J.I., Stocker, A., Trindade, S.C., Vale, V., Brito, T., Bastos, B., Raynal, J.T., Miranda, P.M., Alcantara, A.C., Freire, S.M., Costa, L.M. and Meyer, R. (2018) In vivo and in vitro expression of five genes involved in Corynebacterium pseudotuberculosis virulence. $A M B$ Expr., 8(1): 89.

27. Khamis, A., Raoult, D. and La Scola, B. (2004) rpoB gene sequencing for identification of Corynebacterium species. J. Clin. Microbiol., 42(9): 3925-3931.

28. Pacheco, L.G.C., Pena, R.R., Castro, T.L.P., Dorella, F.A., Bahia, R.C., Carminati, R., Frota, M.N.L., Oliveira, S.C., Meyer, R., Alves, F.S.F., Miyoshi, A. and Azevedo, V. (2007) Multiplex PCR assay for identification of Corynebacterium pseudotuberculosis from pure cultures and for rapid detection of this pathogen in clinical samples. J. Med. Microbiol., 56(4): 480-486.

29. Britten, A.M. (2012) The role of diagnostic microbiology in mastitis control programs. Vet. Clin. N. Am. Food Anim. Pract., 28(2): 187-202.

30. Ashraf, A. and Imran, M. (2018) Diagnosis of bovine mastitis: From laboratory to farm. Trop. Anim. Health Prod., 50(6): 1193-1202.

31. Jashari, R., Piepers, S. and De Vliegher, S. (2016) Evaluation of the composite milk somatic cell count as a predictor of intramammary infection in dairy cattle. J. Dairy Sci., 99(11): 9271-9286.

32. Schukken, Y.H., Wilson, D.J., Welcome, F., GarrisonTinofsky, L. and Gonzales, R.N. (2003) Monitoring udder health and milk quality using somatic cell counts. Vet. Res., 34(5): 579-596.

33. Paape, M.J. and Capuco, A.V. (1997) Cellular defense mechanisms in the udder and lactation of goats. J. Anim. Sci., 75(2): 556-565.

34. Schaeren, W. and Maurer, J. (2006) Prevalence of subclinical udder infections and individual somatic cell counts in three dairy goat herds during a full lactation. Schweiz Arch. Tierheilkd, 148(12): 641-648.

35. Cantekin, Z., Ergün, Y., Doğruer, G., Saribay, M.K. and Solmaz, H. (2015) Comparison of PCR and culture methods for diagnosis of subclinical mastitis in dairy cattle. Kafkas Univ. Vet. Fak. Derg., 21(2): 277-282.

36. Charaya, G., Sharma, A., Kumar, A., Goel, P. and Singh, M. (2015) Detection of major mastitis pathogens by multiplex polymerase chain reaction assay in buffalo milk. Indian $J$. Anim. Sci., 85(3): 122-125.

37. Ashraf, A., Imran, M., Yaqub, T., Tayyab, M., Shehzad, W. and Thomson, P.C. (2017) A novel multiplex PCR assay for simultaneous detection of nine clinically significant bacterial pathogens associated with bovine mastitis. Mol. Cell. Probe., 33: 57-64.

38. Kelly, W.G. (1984) Veterinary Clinical Diagnosis. $3^{\text {rd }}$ ed. Bailliere Tindall, London.

39. Sztachańska, M., Barański, W., Janowski, T., Pogorzelska, J. and Zduńczyk, S. (2016) Prevalence and etiological agents of subclinical mastitis at the end of lactation in nine dairy herds in North-East Poland. Pol. J. Vet. Sci., 19(1):119-24.

40. Rebouças, M.F., Portela, R.W., Lima, D.D., Loureiro, D., Bastos, B.L., Moura-Costa, L.F., Vale, V.L., Miyoshi, A., Azevedo, V. and Meyer, R. (2011) Corynebacterium pseudotuberculosis secreted antigen-induced specific gamma-interferon production by peripheral blood leukocytes: Potential diagnostic marker for caseous lymphadenitis in sheep and goats. J. Vet. Diagn. Invest., 23: 213-220. 
41. Ilhan, Z. (2013) Detection of Corynebacterium pseudotuberculosis from sheep lymph nodes by PCR. Revue. Méd. Vét., 164(2): 60-66.

42. Sammra, O., Balbutskaya, A., Hijazin, M., Nagib, S., Alber, J., Lämmler, C., Abdulmawjood, A., PrengerBerninghoff, E., Timke, M., Kostrzewa, M. and Siebert, U. (2014) Further studies on Arcanobacterium phocisimile: A novel species of genus Arcanobacterium. J. Vet. Med., 2014(3): 923592.

43. Blood, D.C. and Radostits, O.M. (1989) Veterinary Medicine. $7^{\text {th }}$ ed. Saunders, San Diego, CA. p501-559.

44. Petersson-Wolfe, C.S., Tholen, A.R., Currin, J. and Leslie, K.E. (2013) Practical methods for mastitis control. WCDS Adv. Dairy Technol., 25(11): 341-358.

45. Menzies, P.I. and Ramanoon, S.Z. (2001) Mastitis of sheep and goats. Vet. Clin. N. Am. Food Anim. Pract., 17(2): 333-358.

46. Peixoto, R.M., Mota, R.A. and Costa, M.M. (2010) Small ruminant mastitis in Brazil. Pesq. Vet. Bras., 30(9): 754-762.

47. Zhao, Y., Liu, H., Zhao, X., Gao, Y., Zhang, M. and Chen, D. (2015) Prevalence and pathogens of subclinical mastitis in dairy goats in China. Trop. Anim. Health Prod., 47(2): 429-435.

48. Sreeja, S., Bineesh, P.P., Vijayakumar, K. and Saseendranath, M.R. (2013) Evaluation of California mastitis test (CMT) as a screening method for subclinical mastitis in Malabari goats. Indian J. Anim. Res., 47(6): 558-560.

49. Koop, G., De Visscher, A., Collar, C.A., Bacon, D.A., Maga, E.A., Murray, J.D., Supré, K., De Vliegher, S., Haesebrouck, F., Rowe, J.D., Nielen, M. and van Werven, T. (2012) Short communication: Identification of coagulase-negative Staphylococcus species from goat milk with the API Staph identification test and with transfer RNAintergenic spacer PCR combined with capillary electrophoresis. J. Dairy Sci., 95(12): 7200-7205.

50. Marogna G, Pilo C, Vidili A, Tola S, Schianchi G. and Leori SG (2012) Comparison of clinical findings, microbiological results, and farming parameters in goat herds affected by recurrent infectious mastitis. Small Rumin. Res., 102(3): 74-83.

51. McDougall, S., Malcolm, D. and Prosser C.G. (2014) Prevalence and incidence of intramammary infections in lactating dairy goats. N. Z. Vet. J., 62(2): 136-145.
52. Contreras, A., Paape, M.J., Di Carlo, A.L., Miller, R.B. and Rainard, P. (1997) Evaluation of selected antibiotic residue screening tests for milk from individual goats. J. Dairy Sci., 80(6): 1113-1118.

53. Salaberry, S.R., Saidenberg, A.B., Zuniga, E., Melville, P.A., Santos, F.G., Guimarães, E.C., Gregori, F. and Benites N.R. (2015) Virulence factors genes of Staphylococcus spp. Isolated from caprine subclinical mastitis. Microb. Pathog., 85(85): 35-39.

54. Valli, V.E.O. and Parry, B.W. (1993) Caseous lymphadenitis. In: Jubb, K.V.F., Kennedy, P.C. and Palmer. N., (Ed.) Pathology of Domestic Animals. $4^{\text {th }}$ ed., Vol. 3. Academic Press, San Diego. pp238-240.

55. Peel, M.M., Palmer, G.G., Stacpoole, A.M. and Kerr, T.G. (1997) Human lymphadenitis due to Corynebacterium pseudotuberculosis: Report of ten cases from Australia and review. Clin. Infect. Dis., 24(2): 185-191.

56. Stoops, S.G., Renshaw, H.W. and Thilsted, J.P. (1984) Ovine caseous lymphadenitis: Disease prevalence, lesion distribution, and thoracic manifestations in a population of mature culled sheep from Western United States. Am. J. Vet. Res., 45(3): 557-561.

57. McDougall, S., Pankey, W., Delaney, C., Barlow, J., Murdough, P.A. and Scruton, D. (2002) Prevalence and incidence of subclinical mastitis in goats and dairy ewes in Vermont, USA. Small Rumin. Res., 46(2): 115-121.

58. Hodgson, A.L., Bird, P. and Nisbet, I.T. (1990) Cloning, nucleotide sequence, and expression in Escherichia coli of the phospholipase D gene from Corynebacterium pseudotuberculosis. J. Bacteriol., 172(3): 1256-1261.

59. Yozwiak, M.L. and Songer, J.G. (1993) Effect of Corynebacterium pseudotuberculosis phospholipase D on viability and chemotactic responses of ovine neutrophils. Am. J. Vet. Res., 54(3): 392-397.

60. Simmons, C.P., Dunstan, S.J., Tachedjian, M., Krywult, J., Hodgson, A.L. and Strugnell, R.A. (1998) Vaccine potential of attenuated mutants of Corynebacterium pseudotuberculosis in sheep. Infect. Immun., 66(2): 474-479.

61. Eggleton, D.G., Middleton, H.D., Doidge, C.V. and Minty, D.W. (1991) Immunisation against ovine caseous lymphadenitis: Comparison of Corynebacterium pseudotuberculosis vaccines with and without bacterial cells. Aust. Vet. J., 68(10): 317-319.

\section{$* * * * * * * *$}

